УДК 377.091.313:[63+69+629.33/.36]

\title{
ДІАГНОСТИЧНИЙ АНАЛІЗ СТАНУ ГОТОВНОСТІ УЧНІВ ПТНЗ ДО ПРОЕКТНОГО НАВЧАННЯ
}

\author{
Наталя Кулалаєва, \\ кандидат хімічних наук, доцент, \\ завідувач лабораторії технологій професійного навчання \\ Інституту професійно-технічної освіти НАПН Украӥни
}

\section{КЛЮЧОВІ СЛОВА:}

готовність до проектного навчання, проектні технології, професійно-технічні навчальні заклади, діагностичний аналіз, критерії готовності, учні професійнотехнічних навчальних закладів

\begin{abstract}
Реферат
У статті наведено результати діагностичного аналізу стану готовності учнів професійно-технічних навчальних закладів до проектного навчання. Обгрунтовано доцільність застосування проектного навчання у професійній підготовці майбутніх кваліфікованих робітників. Сформульовано й уточнено суть дефініцій «методичні засади розроблення проектних технологій» та «готовність учнів професійнотехнічних навчальних закладів до проектного навчання». Визначено структуру цієї готовності та її компоненти: мотиваційний (усвідомлення цілей, мотиви проектної діяльності у професійній підготовці); змістовий (знання суті проектного навчання, методів і форм групової взаємодії) та особистісно-діяльнісний (інформаційноаналітичні, організаційні, комунікативні, технологічні вміння, рефлексивні здібності тощо). Наведено критерії й показники готовності учнів ПТНЗ до проектного навчання: мотиваційний (оцінка цікавості і корисності проектів; цікавість до певних форм і видів проектів), змістовий (уявлення про метод проектів; знання суті проектного навчання, методів і форм групової взаємодії) та особистісно-діяльнісний (досвід участі у проектній діяльності; володіння вміннями для проектного навчання; оцінка вмінь участі у проектному навчанні; наявність якостей особистості, необхідних для здійснення проектного навчання).

3'ясовано ставлення учнів ПТНЗ до проектних технологій у їхній професійній підготовці. Виявлено пріоритетні для майбутніх кваліфікованих робітників види і зміст проектного навчання у ПТНЗ. Виокремлено предмети, під час вивчення яких учні висловили бажання застосовувати проектне навчання. Наведено розподіл учнів за рівнями сформованості визначених автором компонентів їхньої готовності до проектного навчання у ПТНЗ. Представлено дані самооцінки учнями ПТНЗ своїх умінь для реалізації проектного навчання.

На основі отриманих результатів аналізу сформульовано рекомендації для працівників Департаментів освіти й науки обласних державних адміністрацій України, навчально (науково)-методичних центрів (кабінетів) професійно-технічної освіти України та педагогічних працівників закладів професійно-технічної освіти.
\end{abstract}

Постановка проблеми. Сьогодні в Україні, як ніколи, відчувається дефіцит професійно мобільних, конкурентоспроможних на ринку праці, здатних до підприємницької діяльності висококваліфікованих робітників. Почасти це зумовлено відставанням змісту професійнотехнічної освіти від потреб профільних підприємств - замовників кадрів, повільного оновлення у ПТНЗ основних форм, методів і засобів професійного навчання. У цьому контексті постає необхідність системно впроваджувати у ПТНЗ інноваційні педагогічні технології, зокрема технології проектного професійного навчання [1, с. 29]. Такі технології надзвичайно ефективні для професійної освіти, насамперед тому, що забезпечують здобуття майбутніми кваліфікованими робітниками професійних компетентностей $\mathrm{y}$ тісному зв'язку 3 реальною фаховою практикою та дають можливість підготувати їх до комплексної реалізації професійних функцій. Це означає, що під час навчання у ПТНЗ вихованців мають навчати критично мислити, планувати власну безпечну діяльність, висловлювати та доводити свої думки, презентувати результати власної праці. У майбутніх кваліфікованих робітників необхідно розвивати вміння аналізувати навчальну інформацію та виробничі ситуації, самостійно вирішувати проблеми, співпрацювати в команді тощо. Оскільки крім вищеозначених умінь створюється можливість виховувати в учнів ПТНЗ відповідальність, самостійність, організованість, комунікативність, 
дисциплінованість, безпосередньо - культуру безпеки професійної діяльності [2, с. 75].

При цьому треба зазначити, що відповідні дії щодо покращення такої ситуації певним чином відбуваються у системі професійно-технічної освіти. По-перше, за цих питань започатковується активна співпраця ПТНЗ із підприємствамироботодавцями. По-друге, розробляються нові державні стандарти на компетентнісний основі для пріоритетних робітничих професій. По-третє, на базі ПТНЗ за підтримки держави та підприємств-соціальних партнерів створюються сучасні навчально-практичні центри, котрі забезпечуються новітніми обладнанням, матеріалами, технікою та інструментом. По-четверте, запроваджуються елементи дуальної форми навчання у професійну підготовку майбутніх кваліфікованих робітників [3, с. 7.]. Прийнято Закон України «Про освіту», в якому основною метою професійної освіти проголошено формування та розвиток професійних компетентностей особи, потрібних для здійснення професійної діяльності, забезпечення конкурентоздатності, мобільності та перспектив кар'єрного зростання впродовж життя [4].

Аналіз останніх досліджень. Питанням упровадження інноваційних педагогічних технологій у систему професійної освіти присвячені дослідження В. Бикова, Р. Гуревича, I. Зязюна, О. Коваленко, П. Лузана, А. Нікуліна, Н. Ничкало, В. Радкевич, О. Щербак. Аспекти розроблення та використання проектних технологій у професійній освіті вивчали О. Коберник, А. Литвин, П. Лузан, Є. Полат, Г. Романова, 3. Шацька та ін. Суть педагогічного проектування та можливості його застосування в середній і вищій освіті розкриває у своїх працях О. Коберник [5]. Позитивні та негативні аспекти проектноорієнтованого навчання 3 використанням інформаційних технологій у професійній підготовці робітників-будівельників досліджує А. Литвин [6]. Питання підготовки педагогічних працівників системи професійно-технічної освіти до розроблення та застосування проектних технологій вивчає Г. Романова [7, с. 55]. Але системного дослідження щодо визначення стану готовності учнів професійно-технічних навчальних закладів України до проектного навчання під час їхньої професійної підготовки виявлено не було.

Мета роботи полягає в діагностичному аналізі стану готовності учнів ПТНЗ до проектного навчання для створення освітніх продуктів шляхом оцінювання рівнів іiі сформованості засобами анкетування та розробленні на основі отриманих даних рекомендацій для педагогічних працівників системи професійно-технічної освіти.

Виклад основного матеріалу. Упродовж 2016-2018 pp. в Інституті професійно-технічної освіти НАПН України здійснюється науково-дослідна робота з теми «Методичні засади розроблення проектних технологій для професійної підготовки майбутніх кваліфікованих робітників аграрної, будівельної та автотранспортної галузей». На констатувальному етапі цього дослідження співробітники лабораторії технологій професійного навчання провели комплексне опитування учнів ПТНЗ України з метою визначення рівнів їхньої готовності до проектного навчання. У ході попередньо проведеного теоретичного аналізу сучасних наукових праць, дотичних до означеної проблематики, було сформульовано й уточнено суть дефініцій, що використовуються у дослідженні, котре наведено нижче.

Методичні засади розроблення проектних технологій - комплекс взаємопов'язаних та взаємозумовлених методів, форм і засобів планування, організації, мотивації, контролю, аналізу та коригування проектного професійного навчання, спрямованих на підвищення результативності професійної підготовки учнів ПТНЗ.

Готовність учнів професійно-технічних навчальних закладів до проектного навчання - цілісне внутрішне особистісне утворення, що характеризується здатністю учнів до самостійного отримання необхідних знань, індивідуального та групового виконання пізнавальних, дослідницьких, конструкторських та інших завдань, що завершуються створенням освітніх продуктів. Також було обгрунтовано структуру готовності, визначено, що вона складається 3 мотиваційного (усвідомлення цілей, мотиви 
Наталя Кулалаєва Діагностичний аналіз стану готовності учнів професійно-технічних навчальних закладів до проектного навчання

проектної діяльності у професійній комунікативні, технологічні вміння, підготовці); змістового (знання суті рефлексивні здібності тощо) компонентів. проектного навчання, методів і форм групової Визначено критерії і показники готовності взаємодіï) та особистісно-діяльнісного учнів ПТНЗ до проектного навчання (рис. 1). (інформаційно-аналітичні, організаційні,

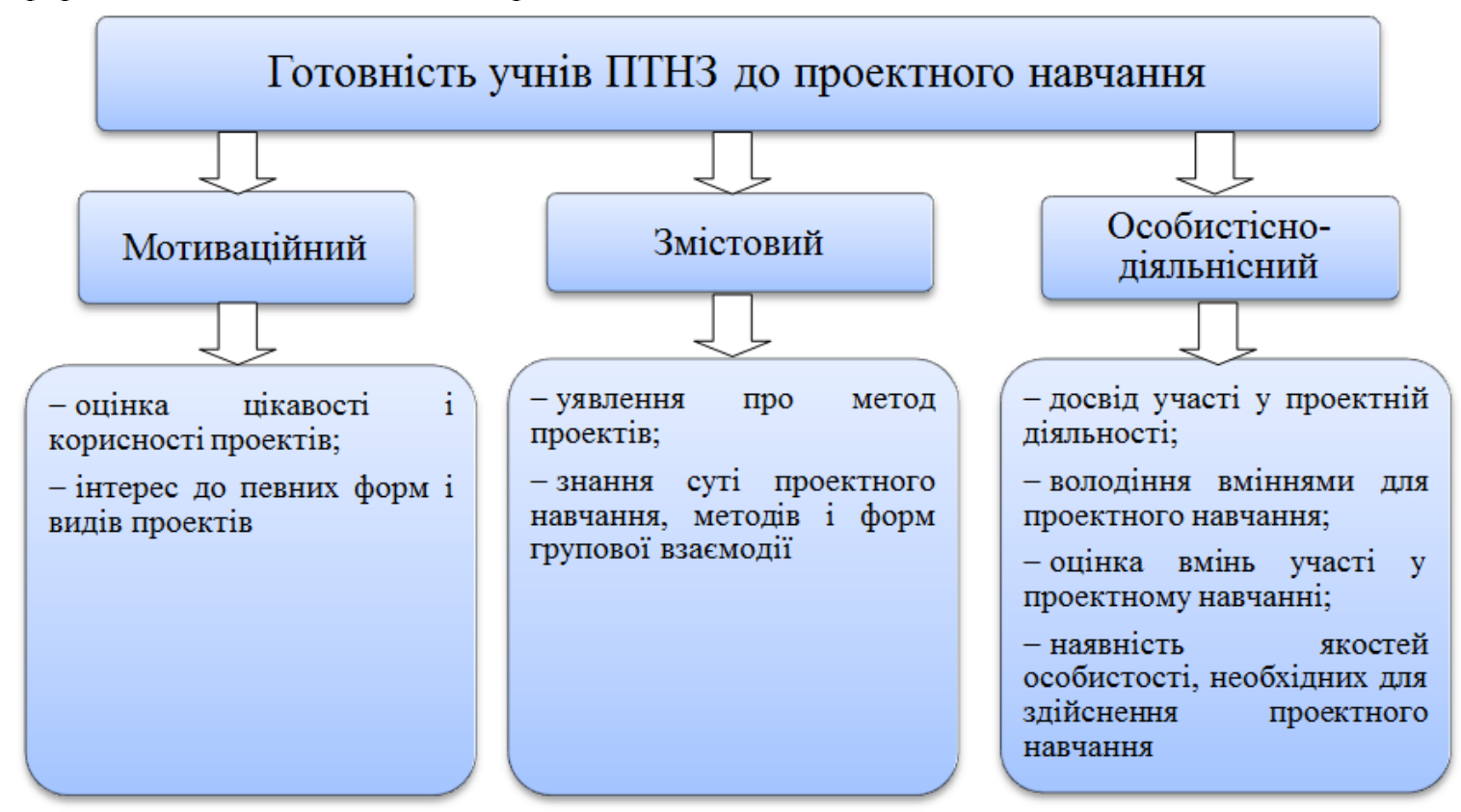

Рис. 1. Критерії та показники готовності учнів ПТНЗ до проектного навчання

Співробітниками лабораторії технологій професійного навчання Інституту ПТО НАПН України було розроблено анкету готовності учнів до проектного навчання у ПТНЗ. Для забезпечення більшої об'єктивності відповідей опитування проводилося анонімно. Анкети включали як відкриті, так і закриті запитання, а також їх поєднання (у закритих запитаннях пропонувалося вказати також, за бажанням, свій варіант відповіді).

Враховуючи те, що в дослідженні планувалося охопити значну вибірку респондентів, було обрано форму інтернетопитування за допомогою веб-сервісу Google Forms. Цей сервіс дає можливість розмістити електронну версію анкети, зібрати та швидко опрацювати результати опитування, а також скопіювати зібраний матеріал для його подальшого опрацювання у спеціальних статистичних програмах, зокрема SPSS.

В опитуванні учнів ПТНЗ щодо готовності до проектного навчання у професійній підготовці взяли участь 6611 учнів із усіх областей України. 3 них: 2214 учнів, які здобувають будівельні професії, 1848 учнів, котрі здобувають професії, пов'язані з автотранспортною галуззю, 1099 учнів, які здобувають сільськогосподарські професії. Серед опитаних були вихованці різного віку, статі та профілю майбутньої професіï.

Анкетне опитування дало змогу 3'ясувати ставлення учнів ПТНЗ до проектних технологій у їхній професійній підготовці. Розподіл відповідей учнів на запитання, що стосувалися пріоритетних для них видів i змісту проектного навчання у ПТНЗ, наведено в табл. 1. Отже, обираючи найцікавішу проектну діяльність у професійній підготовці, майбутні кваліфіковані робітники на перше місце поставили відповідь «шукати й аналізувати цікаву інформацію» (2821 осіб), що, на нашу думку, може бути пов'язане 3 їхньою необізнаністю щодо інших видів проектної діяльності у професійній підготовці, оскільки педагоги в навчальновиробничому процесі надають перевагу саме інформаційним проектам. На друге місце вихованці поставили відповідь «проводити дослідження, експериментувати» (2436 осіб), що свідчить про їхню зацікавленість дослідницькою діяльністю; на третє - 
Розділ II. Методичні засади професійного навчання майбутніх фахівців

«вирішувати реальну проблему» (2150 осіб), тобто це ті учні, які виявили бажання до конкретних дій, спрямованих на отримання реального результату; четверте - «створювати новий продукт» (2043 осіб).

Табличя 1.

Розподіл відповідей учнів на запитання щодо пріоритетних для них видів і змісту проектної діяльності у ПТНЗ

\begin{tabular}{|c|c|c|}
\hline № 3/II & Запитання & "Розподіл відповідей \\
\hline 1 & 2 & 3 \\
\hline 1. & $\begin{array}{l}\text { Яку проектну } \\
\text { діяльність у } \\
\text { професійній } \\
\text { підготовці Вам було б } \\
\text { виконувати цікавіше? } \\
\text { (можна вказати кілька } \\
\text { відповідей) }\end{array}$ & $\begin{array}{l}\text { I - «шукати й аналізувати цікаву інформацію» (2821 осіб); } \\
\text { II - «проводити дослідження, експериментувати» (2436 осіб); } \\
\text { III - «вирішувати реальну проблему» }(2150 \text { осіб); } \\
\text { IV - «створювати новий продукт» (2043 осіб); } \\
\text { V - «з одного предмета» (1223 осіб); } \\
\text { VI - «готувати виставу чи знімати відеофільм» (1147 осіб); } \\
\text { VII - «з кількох предметів» (970 осіб) }\end{array}$ \\
\hline 2. & $\begin{array}{l}3 \text { яких предметів Вам } \\
\text { хотілось би } \\
\text { виконувати проект? }\end{array}$ & $\begin{array}{l}\text { Професійно-теоретичні - 31,3 \% (2069 осіб) } \\
\text { Природничо-математичні - 30,0 \% (1982 особи) } \\
\text { Суспільно-гуманітарні - 14,3 \% (945 осіб) } \\
\text { Загальнопрофесійні - 11,6 \% (767 осіб) } \\
\text { Виробниче навчання - 8,7 \% (577 осіб) } \\
\text { Важко сказати - 4,1 \% (272 особи) }\end{array}$ \\
\hline
\end{tabular}

Із предметів, за якими хотілось би виконувати проект, учні надали перевагу професійно-теоретичним $\quad(31,3 \%) \quad$ та природничо-математичним (30,0\%); водночас, менший інтерес проявили до проектів із суспільно-гуманітарних $\quad(14,3 \%)$ загальнопрофесійних предметів (11,6\%). Виявлене може бути пов'язано 3 обмеженістю навчально-методичного забезпечення названих предметів. Серед форм проектної діяльності учні надали перевагу роботі в парах $(50,8 \%)$ та роботі в малих групах (39,7\%). Водночас, самостійне виконання проекту для учнів $\epsilon$ складним завданням (29\%).

3 метою виявлення рівнів сформованості змістового компонента готовності учнів до проектного навчання у ПТНЗ, перед ними було поставлено запитання: «Чи знають вони про метод проектів?» Більша частина відповідей була позитивною $(66,9 \%)$, однак третина опитаних $(33,1 \%)$ відповіла негативно. Результати засвідчили, що проектне навчання ще недостатньо впроваджується у ПТНЗ. Це підтверджується також і відповідями учнів про використання педагогами методу проектів: ніколи не використовують - 7,8\%; намагаються використовувати, але не дуже успішно - 19,4 \%; успішно використовують 3 окремих предметів - 52,8\%; постійно та успішно використовують 3 більшості предметів - $20 \%$. З'ясовано, що більше половини опитаних учнів мають низький або середній рівень пізнань щодо проектного навчання у ПТНЗ.

Для визначення рівнів сформованості особистісно-діяльнісного компонента готовності, учням пропонувалося оцінити рівень сформованості вмінь, важливих для реалізації проектного навчання у ПТНЗ (табл. 2).

Опитані вважають, що більшою мірою в них сформовані комунікативні та інформаційно-пошукові вміння. Водночас, вихованцям не вистачає презентаційних умінь. Учням також було запропоновано відповісти на запитання: «Чи брали Ви коли-небудь участь у роботі над проектом?» Третина опитаних (33,1\%) відповіла, що не має такого досвіду. Більше половини опитаних відповіли, що мають фрагментарний досвід проектного навчання у ПТНЗ (такий досвід вони мають лише 3 окремих предметів, і один чи декілька разів упродовж навчально-виробничої діяльності брали участь у проектах). 
Наталя Кулалаєва Діагностичний аналіз стану готовності учнів професійно-технічних навчальних закладів до проектного навчання

Табличя 2.

Самооцінка учнями ПТНЗ умінь для реалізації проектного навчання

\begin{tabular}{||l|c|c|c||}
\hline \multirow{2}{*}{\multicolumn{1}{|c|}{ Групи вмінь }} & \multicolumn{3}{|c|}{ Розподіл за рівнями } \\
\cline { 2 - 4 } & низький & середній & високий \\
\hline Планувальні & $12,6 \%$ & $58,7 \%$ & $28,7 \%$ \\
\hline $\begin{array}{l}\text { Інформаційно-пошукові, } \\
\text { дослідницькі }\end{array}$ & $13,0 \%$ & $53,4 \%$ & $33,6 \%$ \\
\hline Комунікативні & $9,1 \%$ & $51,7 \%$ & $39,2 \%$ \\
\hline Презентаційні & $17,2 \%$ & $57,7 \%$ & $25,1 \%$ \\
\hline Рефлексивні & $11,3 \%$ & $59,7 \%$ & $29,0 \%$ \\
\hline
\end{tabular}

Переважній частині $(44,15 \%)$ опитаних учнів притаманний середній рівень готовності до проектного навчання у ПТНЗ, основний внесок при цьому належить саме іiі мотиваційному компоненту. Низький рівень готовності виявили $13,73 \%$, високий -
$41,93 \%$ опитаних. Водночас, за результатами експерименту визначено, що найменше в учнів сформований особистісно-діяльнісний компонент цієї готовності, його формування й потребує особливої уваги (табл. 3).

Таблиия 3.

Готовність учнів ПТНЗ до проектної діяльності

\begin{tabular}{||c|c|c|c||}
\hline \multirow{2}{*}{$\begin{array}{c}\text { Компоненти } \\
\text { готовності }\end{array}$} & низький & Резподіл за рівнямий & високий \\
\cline { 2 - 4 } & $11,60 \%$ & $25,00 \%$ & $63,40 \%$ \\
\hline Мотиваційний & $20,45 \%$ & $36,10 \%$ & $43,45 \%$ \\
\hline Змістовий & $11,40 \%$ & $57,70 \%$ & $30,90 \%$ \\
\hline $\begin{array}{c}\text { Особистісно- } \\
\text { діяльнісний }\end{array}$ & & \\
\hline
\end{tabular}

Отже, в ході діагностичного аналізу стану готовності учнів ПТНЗ до проектного навчання було виявлено:

- потенціал проектних технологій у підготовці кваліфікованих робітників автотранспортної, будівельної, аграрної галузей повноцінно не реалізується, оскільки перевага надається окремим видам проектів, зокрема інформаційним;

- недостатня увага приділяється розробці й застосуванню міждисциплінарних проектів, не повною мірою використовуються можливості інформаційних технологій;

- більшій частині опитаних учнів притаманний середній рівень готовності до проектного навчання, основний внесок у який забезпечує саме iï мотиваційний компонент. Зауважимо, що найменше в учнів ПТНЗ сформований особистісно-діяльнісний компонент цієї готовності.

На основі викладеного сформульовано низку рекомендацій. На регіональному рівні (для Департаментів освіти і науки обласних державних адміністрацій України, навчально (науково)-методичних центрів (кабінетів) професійно-технічної освіти України) доцільно:

- вийти 3 клопотанням до $\mathrm{MOH}$ України щодо організації на базі НМЦ(К) ПТО України тренінгів із залученням співробітників Інституту професійнотехнічної освіти НАПН України для методистів, керівників та педагогічних працівників ПТНЗ із розроблення проектних технологій професійного навчання;

- на базі методичних центрів i кабінетів професійно-технічної освіти створити бази проектів, виконаних у ПТНЗ, технікумах і коледжах;

- створити горизонтальну мережу обміну інноваційним досвідом у сфері проектної діяльності у професійній підготовці майбутніх кваліфікованих робітників;

- вивчати умови ефективної реалізації проектних технологій у професійній підготовці майбутніх кваліфікованих робітників. 
На рівні закладів професійно-технічної освіти доцільно:

- розвивати в учнів ПТНЗ творчі, цільові, аналітичні, демонстраційні та комунікаційні вміння і навички, що потребує застосування сучасних інтерактивних форм $\mathrm{i}$ методів навчання;

- планувати застосування проектних технологій професійного навчання $\mathrm{y}$ навчальних програмах, навантаженні педагогів із урахуванням особливостей проектної діяльності;

- здійснювати розроблення навчальнометодичного забезпечення та підготовку учнів і педагогів ПТНЗ до використання проектних технологій у професійному навчанні. професійної освіти і навчання в контексті євроінтеграції: науковий супровід / В. Радкевич // Науково-методичне забезпечення професійної освіти і навчання: збірник матеріалів XI Всеукраїнської науковопрактичної конференції (звітної), присвяченої 25-річчю НАПН України (м. Київ, 29 березня - 13 квітня 2017 р.) / Інститут професійнотехнічної освіти НАПН України / за заг. ред. В. О. Радкевич. - К.: ІПТО НАПН України, 2017. -300 c. - C. 27-32.

2. Кулалаєва Н. В. Проектне навчання як умова набуття досвіду безпечної праці майбутніми будівельниками / Н. В. Кулалаєва // Науковий вісник Інституту професійнотехнічної освіти НАПН України. Професійна педагогіка: зб. наук. праць. - 2016. - Вип. 12. - C. $75-84$.

3. Кучинський М. Модернізація професійно-технічної освіти в контексті розвитку людського капіталу України на період до 2020 року / М. Кучинський // Професійно-технічна освіта. - 2017. - № 1. C. 5-9.
Висновок. Системне запровадження проектного навчання у ПТНЗ приводить до того, що учні поступово опановують його не тільки як навчальну технологію, вміння самостійно вчитися, критично мислити, але також як метод організації та планування подальшої професійної діяльності. Таке навчання сприятиме усуненню дефіциту професійно мобільних, конкурентоспроможних на ринку праці, здатних до підприємницької діяльності висококваліфікованих робітників. Використання проектних технологій під час запровадження елементів дуальної форми навчання в ПТНЗ дасть змогу привести у відповідність зміст, методи, форми й засоби професійного навчання з потребами профільних підприємств - замовників кадрів.

\section{Література}

4. Закон України «Про освіту» // (Відомості Верховної Ради (ВВР), 2017, № 38-39, ст. 380). - [Електронний ресурс] Режим http://zakon2.rada.gov.ua/laws/show/214519/page.

5. Коберник О. M. Проектна технологія: можливості застосування в освіті / О. М. Коберник. - [Електронний ресурс] Режим доступу: http://dspace.udpu.org.ua:8080/jspui/bitstream/67 89/2395/1/Kobernik\%200_\%20proektna\%20tex nologia.pdf. - Назва з екрану.

6. Литвин А. Проектно-орієнтовані методи навчання робітників-будівельників із застосуванням ІКТ / А. Литвин. [Електронний ресурс] - Режим доступу: http://lib.iitta.gov.ua/4937/1/St_Литвин_Проек_ орієнт методи.pdf.

7. Ганна Романова. Застосування проектних технологій i формуванні особистісно-розвивального середовища ПТНЗ / Ганна Романова // Науковий вісник Інституту професійно-технічної освіти НАПН України. Професійна педагогіка: зб. наук. праць. - 2016. - Вип. 11. - С. 54-62. 


\section{Реферат}

\section{Диагностический анализ состояния готовности учащихся ПТУЗ к проектному обучению}

Наталья Кулалаева, кандидат химических наук, дочент, заведующая лабораторией технологий профессионального обучения Института профессионально-технического образования НАПН Украины

\section{КЛЮЧЕВЫЕ СЛОВА:}

готовность к проектному обучению, проектные технологии, профессиональнотехнические учебные заведения, диагностический анализ, критерии готовности, учащиеся профессиональнотехнических учебных заведений
В статье приведен диагностический анализ состояния готовности учащихся профессионально-технических учебных заведений к проектному обучению. Обоснована целесообразность использования проектного обучения в профессиональной подготовке будущих квалифицированных рабочих. Сформулирована и уточнена суть дефиниций «методические основы разработки проектных технологий» и «готовность учащихся профессионально-технических учебных заведений к проектному обучению». Определены структура готовности и ее компоненты: мотивационный (осознание целей, мотивы проектной деятельности в профессиональной подготовке); содержательный (знание сути проектного обучения, методов и форм группового взаимодействия) и личностно-деятельностный (информационно-аналитические, организационные, коммуникативные, технологические умения, рефлексивные способности и т. д.). Приведены критерии и показатели готовности учащихся ПТУЗ к проектному обучению: мотивационный (оценка интересности и полезности проектов; интерес к определенным формам и видам проектов), содержательный (представление о методе проектов; знание сути проектного обучения, методов и форм группового взаимодействия) и личностно-деятельностный (опыт участия в проектной деятельности; владение умениями для проектного обучения; оценка умений для участия в проектном обучении; наличие качеств личности, необходимых для осуществления проектного обучения).

Выяснено отношение учащихся ПТУЗ к проектным технологиям в их профессиональной подготовке. Выявлены приоритетные для будущих квалифицированных рабочих виды и содержание проектного обучения в ПТУЗ. Выделены предметы, при изучении которых учащиеся проявили желание использовать проектное обучение. Представлено распределение учащихся по уровням сформированности определенных автором компонентов их готовности к проектному обучению в ПТУЗ. Приведены данные самооценки учащимися ПТУЗ своих умений для реализации проектного обучения.

На основании полученных результатов анализа сформулированы рекомендации для работников Департаментов образования и науки областных государственных администраций Украины, учебно (научно)-методических центров (кабинетов) профессионально-технического образования Украины и педагогических работников заведений профессионального образования. 


\title{
Abstract \\ Diagnostic analysis of condition of preparedness of vet-studeents for project education
}

\author{
Natalia Kulalaieva, \\ Ph.D. in Chemistry, associate professor, \\ Head of the Laboratory of professional training technologies \\ of the Institute of Vocational Education and Training \\ of the National Academy of Educational Sciences of Ukraine
}

\section{KEY WORDS:}

readiness for project training, project technologies, VET schools, diagnostic analysis, readiness criteria, VET schools students

\section{References}

1. Radkevych V. Modernizaciya profesijnoyi osvity i navchannya $\mathrm{v}$ konteksti yevrointegraciyi: naukovyj suprovid / Valentyna Radkevych // Naukovo-metodychne zabezpechennya profesijnoyi osvity i navchannya: zbirnyk materialiv XI Vseukrayinskoyi naukovo-praktychnoyi konferenciyi (zvitnoyi), pry`svyachenoyi 25richchyu NAPN Ukrayiny' (m. Kyyiv, 29 bereznya - 13 kvitnya 2017 r.) / Instytut profesijno-texnichnoyi osvity NAPN Ukrayiny` / za zag. red. V. O. Radkevych. - K. : IPTO NAPN Ukrayiny`, 2017. - 300 s. - S. 27-32.

2. Kulalayeva N. V. Proektne navchannya yak umova nabuttya dosvidu bezpechnoyi praci majbutnimy budivelnykamy / N. V. Kulalayeva // Naukovyj visnyk Instytutu profesijnotexnichnoyi osvity NAPN Ukrayiny. Profesijna pedagogika: zb. nauk. Pracz. - 2016. - Vyp. 12. - S. 75-84.

3. Kuchynskyj M. Modernizaciya profesijno-texnichnoyi osvity $\mathrm{v}$ konteksti 
Наталя Кулалаєва Діагностичний аналіз стану готовності учнів професійно-технічних навчальних закладів до проектного навчання

rozvytku lyudskogo kapitalu Ukrayiny na period do 2020 roku / M. Kuchynskyj // Profesijnotexnichna osvita. - 2017. - № 1. - S. 5-9.

4. Zakon Ukrayiny «Pro osvitu» // Vidomosti Verxovnoyi Rady (VVR), 2017, № 38-39, st. 380. - [Elektronnyj resurs]. Rezhym http://zakon2.rada.gov.ua/laws/show/214519/page.

5. Kobernyk O. M. Proektna texnologiya: mozhlyvosti zastosuvannya $\mathrm{v}$ osviti / O. M. Koberny`k. - [Elektronnyj resurs]. Rezhym dostupu: http://dspace.udpu.org.ua:8080/jspui/bitstream/67
89/2395/1/Kobernik\%20O_\%20proektna\%20tex nologia.pdf.

6. Lytvyn A. Proektno-oriyentovani metody navchannya robitnykiv-budivelnykiv iz zastosuvannyam IKT / A. Lytvyn. / A. Lytvyn. [Elektronnyj resurs] - Rezhym dostupu: http://lib.iitta.gov.ua/4937/1/St_Lytvyn_Proek_or iyent_metody.pdf. - Nazva z ekranu.

7. Romanova G. Zastosuvannya proektnyx texnologij i formuvanni osobystisnorozvyvalnogo seredovyshha PTNZ / G. Romanova // Naukovyj visnyk Instytutu profesijno-texnichnoyi osvity NAPN Ukrayiny. Profesijna pedagogika: zb. nauk. pracz. - 2016. Vyp. 11. - S. 54-62. 